\title{
PENGARUH PUPUK KANDANG DAN KONSENTRASI URINE KELINCI TERHADAP PERTUMBUHAN DAN HASIL TANAMAN MENTIMUN (Cucumis sativus L.)
}

Azhar Indra Rusmana, Ari Wijayani dan Ellen Rosyelina Sasmita

Universitas Pembangunan Nasional Veteran Yogyakarta

E-mail: azharindrarusmana77@gmail.com, ariewijayani@yahoo.com dan ellensasmita@gmail.com

\section{Diterima:}

28 September

2021

Direvisi:

10 Oktober 2021

Disetujui:

15 Oktober 2021

\section{Abstrak}

Kondisi lahan pertanian di Indonesia semakin mengalami kerusakan, salah satunya diakibatkan oleh perilaku petani yang lebih menggunakan pupuk anorganik dibandingkan pupuk organik. Penelitian ini bertujuan untuk mengetahui respon pertumbuhan serta hasil berbagai macam pupuk kandang dan konsentrasi urine kelinci terhadap tanaman mentimun. Penelitian ini dilaksanakan pada Januari - Maret 2021 di Desa Wanantara, Kecamatan Sindang, Kabupaten Indramayu. Penelitian ini menggunakan percobaan faktorial, dirancang menggunakan Rancangan Acak Kelompok Lengkap (RAKL) 2 faktor yang diulang sebanyak 3 kali. Faktor pertama, macam pupuk kandang yang terdiri atas 3 taraf yaitu pupuk kandang sapi, pupuk kandang kambing, pupuk kandang ayam. Faktor kedua, konsentrasi urin kelinci yang terdiri atas 4 taraf yaitu $0 \mathrm{ml} / \mathrm{l}$, $100 \mathrm{ml} / 1,200 \mathrm{ml} / 1,300 \mathrm{ml} / \mathrm{l}$. Data dianalisis menggunakan analisis sidik ragam (Anova) dengan taraf 5\%. Uji lanjut perlakuan dilanjutkan dengan DMRT taraf 5\%. Hasil percobaan menunjukkan adanya interaksi pada parameter panjang sulur 1 MST rerata $10,89 \mathrm{~cm}$ dan 2 MST rerata $28,66 \mathrm{~cm}$. Perlakuan pupuk kandang ayam memberikan hasil yang berbeda nyata terhadap panjang sulur 3,4 MST rerata $72,24 \mathrm{~cm} ; 83,25 \mathrm{~cm}$, diameter batang 1,2,3,4 MST rerata 3,96mm; 6,32mm; $8,14 \mathrm{~mm}$; $8,61 \mathrm{~mm}$, jumlah daun 1,2,3,4 MST rerata 5,19 helai; 7,22 helai; 12,06 helai; 12,30 helai, jumlah bunga rerata 4,50 buah, panjang buah rerata $12,56 \mathrm{~cm}$, bobot buah per buah rerata 128,57 gram, bobot buah per tanaman rerata 1324,33 gram, bobot segar tanaman rerata 49,92 gram, dan bobot kering tanaman rerata 22,17 gram. Perlakuan $300 \mathrm{ml} /$ liter memberikan hasil berbeda nyata terhadap diameter batang 1 MST rerata $3,84 \mathrm{~mm}$ dan bobot buah per tanaman rerata 1197,67 dengan produksi mencapai 1104,61 gram/polybag atau 60,8 ton/ha.

Kata kunci: Pupuk Kandang, Urine Kelinci dan Mentimun

\section{Abstract}

The condition of agricultural land in Indonesia is getting more damaged, due to the behavior of farmers who use inorganic fertilizers more than organic fertilizers. This study aims to determine the growth response and the results of the various kinds of manure and rabbit urine concentration of cucumber plants. This research was conducted in january-march 2021 in Wanantara Village, Sindang District, Indramayu Regency. This 


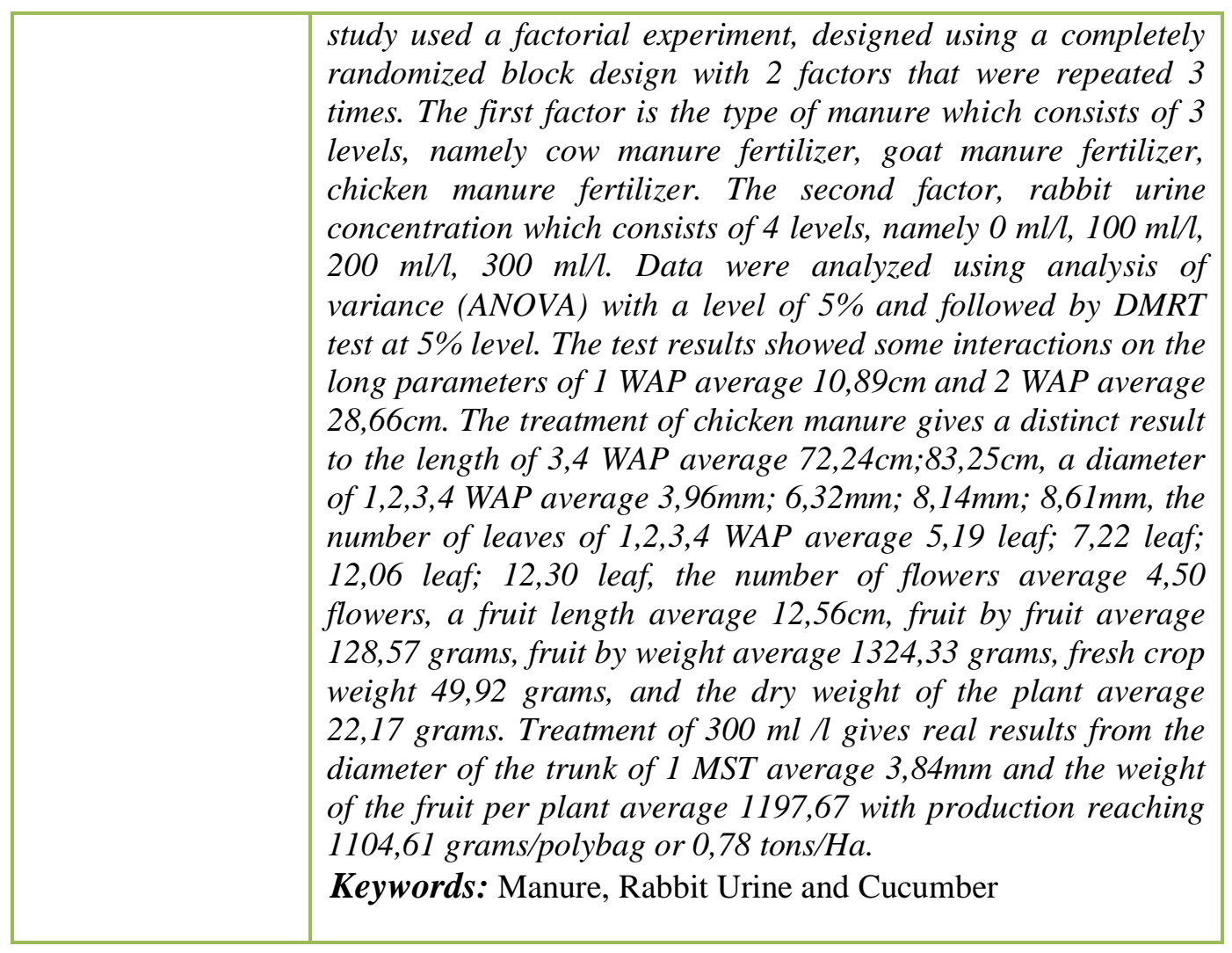

\section{Pendahuluan}

Mentimun (Cucumis sativus) merupakan tanaman sayuran yang kaya akan manfaat dalam kehidupan sehari-hari. Selain dikomsumsi sebagai sayuran dan lalapan, mentimun dapat dimanfaatkan sebagai bahan obat-obatan dan bahan kosmetik (Nurjanah \& Ihsan, 2013). Buah timun memiliki keunggulan di bidang kesehatan karena buah timun memiliki kandungan nutrisi yang tinggi seperti karbohidrat, zat besi, protein, vitamin $\mathrm{C}$, fosfor, dan kalsium serta memiliki efek antibakteri (Noviyandri \& Nasution, 2017).

Penurunan produksi mentimun pada tahun 2017 di Kabupaten Indramayu semula 81,3 ton dan tahun 2018 menurun menjadi 30,1 ton. Berdasarkan data Badan Pusat Statistik 2020, telah terjadi penurunan pada Kecamatan Juntinyuat, Kabupaten Indramayu tahun 2018 produksi mentimun semula 74,1 ton, pada tahun 2019 menurun menjadi 52,8 ton. Oleh sebab itu perlu dilakukan perbaikan teknik budidaya tanaman mentimun. Salah satu teknik budidaya yang intensif untuk meningkatkan hasil panen mentimun adalah pemupukan yang tepat (Masitoh, Puspitorini, \& Widiatmanta, 2018).

Lahan di Jawa mengandung bahan organik sekitar $1 \%$, sedangkan untuk pertumbuhan tanaman hortikultura yang baik diperlukan kandungan bahan organik $2 \%$ (Kardinan, 2016). Rendahnya kandungan bahan organik di Jawa dikarenakan intensifnya penggunaan pupuk kimia sintesis dengan tujuan meningkatkan produksi, namun tidak diimbangi dengan penggunaan bahan organik serta tanpa mempertimbangkan keseimbangan aktivitas biologi di dalam tanah. Pupuk kandang merupakan produk buangan dari binatang peliharaan yang digunakan untuk menambah unsur hara, 
memperbaiki sifat fisik dan biologis tanah yaitu menghidupkan jasad renik atau mikroorganisme dalam tanah (Hartatik, Husnain, \& Widowati, 2015).

Ketergantungan penggunaan pupuk anorganik menjadi salah satu alasan para petani, hal tersebut dikarenakan petani khawatir akan mengalami penurunan produktivitas, sehingga pengurangan penggunaan pupuk anorganik sulit dilakukan. Salah satu upaya yang dapat dilakukan untuk tetap meningkatkan kualitas dan kesuburan tanah dengan penambahan pupuk organik seperti penambahan pupuk organik cair. Pupuk organik cair urine kelinci dinilai memiliki kandungan unsur $\mathrm{N}, \mathrm{P}$ dan $\mathrm{K}$ yang lebih besar daripada kandungan urine ternak lainnya. Urine kelinci mengandung zat perangsang tumbuh yang dapat digunakan sebagai pengatur tumbuh yaitu IAA (Indone Acetic Acid) yang dapat memacu pertumbuhan tanaman, pemberian pupuk organik cair ini harus memperhatikan konsentrasi yang diaplikasikan terhadap tanaman.

Proses interaksi yang terjadi antara perlakuan pupuk kandang dengan pupuk organik cair urine kelinci yaitu, pemberian pupuk kandang mampu meningkatkan bahan organik yang ada di dalam tanah yang berfungsi sebagai sumber nutrisi bagi mikroorganisme (Ruminta, Wahyudin, \& Hanifa, 2017). Pemberian pupuk organik cair mampu mendorong dan meningkatkan pembentukan klorofil daun, sehingga dapat meningkatkan kemampuan fotosintesis tanaman dan penyerapan nitrogen dari udara, dapat meningkatkan vigor tanaman, sehingga tanaman menjadi kokoh dan kuat, meningkatkan daya tahan tanaman terhadap kekeringan, dan serangan hama penyakit, merangsang pertumbuhan dan cabang produksi, meningkatkan pembentukan bunga dan bakal buah, serta mengurangi gugurnya daun, bunga dan bakal buah. Pupuk organik cair lebih mudah diserap oleh tanaman karena unsur-unsur di dalamnya telah terurai (Soraya Santi, 2012). Berdasarkan uraian di atas maka perlu dilakukan penelitian mengenai berbagai macam pupuk kandang dan konsentrasi urine kelinci terhadap pertumbuhan dan hasil tanaman mentimun.

Pupuk kandang 20 ton/ha menghasilkan diameter batang mentimun yang besar (Purnomo, Santoso, \& Heddy, 2013). Aplikasi pupuk kandang ayam pada dosis 15 ton/ha berpengaruh sangat nyata terhadap total produksi buah tanaman mentimun. Dosis urine kelinci $300 \mathrm{ml}$ memberikan hasil tertinggi pada jumlah tandan bunga, jumlah bunga, jumlah buah, berat buah dan berat buah per tanaman strawberry.

\section{Metode Penelitian}

Pelaksanaan penelitian mulai pada bulan Januari-Maret 2021. Penelitian dilaksanakan di Dusun Wanantara Timur, Desa Wanantara, Kecamatan Sindang, Kabupaten Indramayu, Jawa Barat. Ketinggian tempat \pm 18 meter di atas permukaan laut dengan topografi sebagian besar merupakan dataran atau daerah landai dengan kemiringan tanahnya rata-rata 0-2\%. Jenis tanah aluvial. Kadar keasaman $(\mathrm{pH})$ tanah sebesar 7 , suhu minimal rata-rata $\pm 22^{\circ} \mathrm{C}$ dan suhu maksimal rata-rata $32^{\circ} \mathrm{C}$, serta memiliki kelembaban rata-rata $70-80 \%$.

Alat yang digunakan terdiri yaitu cangkul, ember, meteran, sprayer, ajir, tali rafia, timbangan analitik, gelas ukur, gembor, oven, refraktomoter, bak semai, kamera, dan alat tulis. Adapun bahan yang digunakan terdiri yaitu benih mentimun, pupuk organik cair (Urine kelinci), polybag, pupuk kandang kambing, pupuk kandang ayam, dan pupuk kandang sapi.

Penelitian merupakan percobaan lapangan yang disusun secara faktorial dengan Rancangan Acak Kelompok Lengkap (RAKL) dengan dua faktor yang terdiri atas tiga ulangan (Ningrum, 2018). Faktor pertama adalah macam pupuk kandang, yang terdiri atas tiga aras dengan masing-masing dosis sebanyak 141,3 gram/tanaman, yaitu; P1: Pupuk Kandang Sapi, P2: Pupuk Kandang Kambing, P3: Pupuk Kandang Ayam Faktor 
kedua adalah konsentrasi urine kelinci yang terdiri atas empat aras, yaitu; K0: $0 \mathrm{ml} / \mathrm{lt}, \mathrm{K} 1$ : $100 \mathrm{ml} / \mathrm{lt}, \mathrm{K} 2: 200 \mathrm{ml} / \mathrm{lt}, \mathrm{K} 3: 300 \mathrm{ml} / \mathrm{lt}$. Dari kedua faktor tersebut diperoleh, 12 kombinasi perlakuan yang diulang 3 kali dalam 1 kombinasi perlakuan terdapat 8 tanaman, sehingga terdapat 288 tanaman mentimun.

\section{Hasil dan Pembahasan}

Hasil sidik ragam parameter panjang sulur 1 MST dan 2 MST menunjukkan bahwa parameter panjang sulur 1 MST perlakuan pupuk kandang berpengaruh nyata dan konsentrasi urine kelinci tidak berpengaruh nyata. Parameter panjang sulur 2 MST perlakuan pupuk kandang dan konsentrasi urine kelinci berpengaruh nyata. Perlakuan pupuk kandang dan konsentrasi urine kelinci menunjukkan adanya interaksi. Nilai rerata Panjang Sulur 1 MST dan 2 MST dapat dilihat pada tabel 1.

Tabel 1. Rerata panjang sulur 1 MST dan 2 MST pada perlakuan macam pupuk kandang dan konsentrasi urine kelinci $(\mathrm{cm})$

\begin{tabular}{|c|c|c|c|c|}
\hline \multirow{2}{*}{$\begin{array}{l}\text { Urine } \\
\text { Kelinci }\end{array}$} & \multicolumn{3}{|c|}{ Pupuk Kandang } & \multirow[t]{2}{*}{ Rerata } \\
\hline & P1 & $\mathrm{P} 2$ & P3 & \\
\hline \multicolumn{5}{|c|}{ Panjang Sulur 1 MST (cm) } \\
\hline K0 & $12,08 \mathrm{c}$ & $8,21 \mathrm{~g}$ & 9,77 ef & 10,02 \\
\hline $\mathrm{K} 1$ & $12,68 \mathrm{bc}$ & $9,51 \mathrm{f}$ & $9,67 \mathrm{ef}$ & 10,62 \\
\hline $\mathrm{K} 2$ & $10,92 \mathrm{~d}$ & $10,52 \mathrm{de}$ & $13,39 \mathrm{~b}$ & 11,61 \\
\hline $\mathrm{K} 3$ & $10,01 \mathrm{def}$ & 10,06 def & $14,92 \mathrm{a}$ & 11,66 \\
\hline Rerata & 11,42 & 9,58 & 11,94 & $10,89(+)$ \\
\hline \multicolumn{5}{|c|}{ Panjang Sulur 2 MST (cm) } \\
\hline K0 & $31,24 \mathrm{bc}$ & $26,89 \mathrm{de}$ & $26,11 \mathrm{de}$ & 28,08 \\
\hline $\mathrm{K} 1$ & $24,33 \mathrm{e}$ & $25,13 \mathrm{e}$ & $27,56 \mathrm{de}$ & 25,67 \\
\hline $\mathrm{K} 2$ & 27,94 cde & $29,57 \mathrm{bc}$ & $33,11 \mathrm{ab}$ & 30,21 \\
\hline K3 & $24,61 \mathrm{e}$ & $30,10 \mathrm{bc}$ & $37,31 \mathrm{a}$ & 30,67 \\
\hline Rerata & 27,03 & 27,92 & 31,02 & $28,66(+)$ \\
\hline
\end{tabular}

Keterangan: Rerata yang diikuti oleh huruf sama pada kolom yang sama menunjukkan tidak ada beda nyata pada uji Duncan Multiple Range Test pada taraf 5\%. Tanda (+) menunjukkan ada interaksi.

Hasil sidik ragam parameter panjang sulur 3 MST dan 4 MST menunjukkan bahwa perlakuan pupuk kandang berpengaruh nyata dan konsentrasi urine kelinci tidak berpengaruh nyata. Perlakuan pupuk kandang dan konsentrasi urine kelinci menunjukkan tidak ada interaksi. Nilai rerata panjang sulur 3 MST dan 4 MST dapat dilihat pada tabel 2. 
Tabel 2. Rerata panjang sulur 3 MST dan 4 MST pada perlakuan macam pupuk kandang dan konsentrasi urine kelinci $(\mathrm{cm})$.

\begin{tabular}{ccc}
\hline \multirow{2}{*}{ Perlakuan } & \multicolumn{2}{c}{ Minggu Setelah Tanam (MST) } \\
\hline P1 & 3 & 4 \\
P2 & $57,91 \mathrm{~b}$ & $69,83 \mathrm{~b}$ \\
P3 & $55,82 \mathrm{~b}$ & $68,40 \mathrm{~b}$ \\
K0 & $72,24 \mathrm{a}$ & $83,25 \mathrm{a}$ \\
K1 & $61,15 \mathrm{p}$ & $72,00 \mathrm{p}$ \\
K2 & $61,94 \mathrm{p}$ & $75,00 \mathrm{p}$ \\
K3 & $61,19 \mathrm{p}$ & $72,61 \mathrm{p}$ \\
Rerata & $63,67 \mathrm{p}$ & $75,70 \mathrm{p}$ \\
\hline
\end{tabular}

Keterangan: Rerata yang diikuti oleh huruf sama pada kolom yang sama menunjukkan tidak ada beda nyata pada uji Duncan Multiple Range Test pada taraf 5\%. Tanda (-) menunjukkan tidak ada interaksi.

Hasil sidik ragam parameter diameter batang 1,2,3,4 MST menunjukkan bahwa parameter diameter batang 1 MST perlakuan pupuk kandang dan konsentrasi urine kelinci berpengaruh nyata. Parameter diameter batang 2,3,4 MST perlakuan pupuk kandang berpengaruh nyata dan konsentrasi urine kelinci tidak berpengaruh nyata. Perlakuan pupuk kandang dan konsentrasi urine kelinci menunjukkan tidak ada interaksi. Nilai rerata diameter batang 1,2,3,4 MST dapat dilihat pada tabel 3 .

Tabel 3. Rerata diameter batang 1,2,3,4 MST pada perlakuan macam pupuk kandang dan konsentrasi urine kelinci (mm).

\begin{tabular}{ccccc}
\hline \multirow{2}{*}{ Perlakuan } & \multicolumn{4}{c}{ Minggu Setelah Tanam (MST) } \\
& 1 & 2 & 3 & 4 \\
\hline P1 & $3,41 \mathrm{~b}$ & $5,79 \mathrm{~b}$ & $7,03 \mathrm{~b}$ & $7,73 \mathrm{~b}$ \\
P2 & $3,34 \mathrm{~b}$ & $5,35 \mathrm{~b}$ & $7,00 \mathrm{~b}$ & $7,50 \mathrm{~b}$ \\
P3 & $3,96 \mathrm{a}$ & $6,32 \mathrm{a}$ & $8,14 \mathrm{a}$ & $8,61 \mathrm{a}$ \\
\hline K0 & $3,25 \mathrm{r}$ & $5,63 \mathrm{p}$ & $7,44 \mathrm{p}$ & $7,92 \mathrm{p}$ \\
K1 & $3,54 \mathrm{q}$ & $5,79 \mathrm{p}$ & $7,30 \mathrm{p}$ & $7,88 \mathrm{p}$ \\
K2 & $3,64 \mathrm{q}$ & $5,91 \mathrm{p}$ & $7,44 \mathrm{p}$ & $7,96 \mathrm{p}$ \\
K3 & $3,84 \mathrm{p}$ & $5,94 \mathrm{p}$ & $7,38 \mathrm{p}$ & $8,03 \mathrm{p}$ \\
\hline Rerata & $3,57(-)$ & $5,82(-)$ & $7,39(-)$ & $7,95(-)$ \\
\hline
\end{tabular}

Keterangan: Rerata yang diikuti oleh huruf sama pada kolom yang sama menunjukkan tidak ada beda nyata pada uji Duncan Multiple Range Test pada taraf 5\%. Tanda (-) menunjukkan tidak ada interaksi.

Hasil sidik ragam parameter jumlah daun 1,2,3,4 MST menunjukkan bahwa parameter jumlah daun 1,2,3,4 MST perlakuan pupuk kandang berpengaruh nyata dan konsentrasi urine kelinci tidak berpengaruh nyata. Perlakuan pupuk kandang dan konsentrasi urine kelinci menunjukkan tidak ada interaksi. Nilai rerata jumlah daun 1,2,3,4 MST dapat dilihat pada tabel 4. 
Tabel 4. Rerata jumlah daun 1,2,3,4 MST pada perlakuan macam pupuk kandang dan konsentrasi urine kelinci (helai).

\begin{tabular}{ccccc}
\hline \multirow{2}{*}{ Perlakuan } & \multicolumn{5}{c}{ Minggu Setelah Tanam (MST) } \\
& 1 & 2 & 3 & 4 \\
\hline P1 & $5,00 \mathrm{~b}$ & $6,81 \mathrm{~b}$ & $9,22 \mathrm{~b}$ & $9,92 \mathrm{~b}$ \\
P2 & $4,78 \mathrm{~b}$ & $6,17 \mathrm{c}$ & $9,56 \mathrm{~b}$ & $9,61 \mathrm{~b}$ \\
P3 & $5,19 \mathrm{a}$ & $7,22 \mathrm{a}$ & $12,06 \mathrm{a}$ & $12,30 \mathrm{a}$ \\
\hline K0 & $5,00 \mathrm{p}$ & $6,56 \mathrm{p}$ & $10,19 \mathrm{p}$ & $10,33 \mathrm{p}$ \\
K1 & $4,85 \mathrm{p}$ & $6,59 \mathrm{p}$ & $10,04 \mathrm{p}$ & $10,70 \mathrm{p}$ \\
K2 & $5,04 \mathrm{p}$ & $6,63 \mathrm{p}$ & $10,26 \mathrm{p}$ & $10,29 \mathrm{p}$ \\
K3 & $5,07 \mathrm{p}$ & $7,15 \mathrm{p}$ & $10,63 \mathrm{p}$ & $11,11 \mathrm{p}$ \\
\hline Rerata & $4,99(-)$ & $6,73(-)$ & $10,28(-)$ & $10,61(-)$ \\
\hline
\end{tabular}

Keterangan: Rerata yang diikuti oleh huruf sama pada kolom yang sama menunjukkan tidak ada beda nyata pada uji Duncan Multiple Range Test pada taraf 5\%. Tanda (-) menunjukkan tidak ada interaksi.

Hasil sidik ragam parameter jumlah bunga, bobot buah per buah, dan bobot buah per tanaman menunjukkan bahwa parameter jumlah bunga dan bobot buah per buah perlakuan pupuk kandang berpengaruh nyata dan konsentrasi urine kelinci tidak berpengaruh nyata. Parameter bobot buah per tanaman perlakuan pupuk kandang dan konsentrasi urine kelinci berpengaruh nyata. Perlakuan pupuk kandang dan konsentrasi urine kelinci menunjukkan tidak ada interaksi. Nilai rerata jumlah bunga, bobot buah per buah, dan bobot buah per tanaman dapat dilihat pada tabel 5 .

Tabel 5. Rerata jumlah bunga, bobot buah per buah, dan bobot buah per tanaman pada perlakuan macam pupuk kandang dan konsentrasi urine kelinci.

\begin{tabular}{|c|c|c|c|c|}
\hline \multirow{2}{*}{$\begin{array}{c}\text { Urine } \\
\text { Kelinci }\end{array}$} & \multicolumn{3}{|c|}{ Pupuk Kandang } & \multirow[t]{2}{*}{ Rerata } \\
\hline & $\mathrm{P} 1$ & $\mathrm{P} 2$ & P3 & \\
\hline \multicolumn{5}{|c|}{ Panjang Sulur 1 MST (cm) } \\
\hline K0 & 3,00 & 3,33 & 3,11 & $3,15 \mathrm{p}$ \\
\hline K1 & 3,33 & 4,00 & 4,22 & $3,85 \mathrm{p}$ \\
\hline $\mathrm{K} 2$ & 3,56 & 3,22 & 4,89 & $3,39 \mathrm{p}$ \\
\hline K3 & 3,89 & 3,78 & 5,78 & $4,48 \mathrm{p}$ \\
\hline Rerata & $3,45 \mathrm{~b}$ & $3,58 \mathrm{~b}$ & $4,50 \mathrm{a}$ & $3,84(-)$ \\
\hline \multicolumn{5}{|c|}{ Bobot Buah per Buah (gram) } \\
\hline K0 & 106,22 & 76,33 & 115,67 & $96,00 \mathrm{p}$ \\
\hline K1 & 80,72 & 85,89 & 121,17 & $95,93 \mathrm{p}$ \\
\hline $\mathrm{K} 2$ & 79,28 & 102,22 & 139,17 & $106,89 \mathrm{p}$ \\
\hline $\mathrm{K} 3$ & 110,22 & 123,89 & 138,28 & $124,13 \mathrm{p}$ \\
\hline Rerata & $90,07 \mathrm{~b}$ & $97,08 \mathrm{~b}$ & $128,57 \mathrm{a}$ & $105,24(-)$ \\
\hline \multicolumn{5}{|c|}{ Bobot Buah per Tanaman (gram) } \\
\hline K0 & 954,00 & 1048,67 & 1035,33 & $1012,67 \mathrm{r}$ \\
\hline K1 & 995,67 & 1091,33 & 1092,00 & $1059,67 \mathrm{q}$ \\
\hline $\mathrm{K} 2$ & 1147,67 & 1057,00 & 1240,67 & $1148,45 \mathrm{q}$ \\
\hline K3 & 1125,67 & 1143,00 & 1324,33 & $1197,67 \mathrm{p}$ \\
\hline Rerata & $1055,75 \mathrm{~b}$ & $1085,00 \mathrm{~b}$ & $1173,08 \mathrm{a}$ & $1104,61(-)$ \\
\hline
\end{tabular}

Keterangan: Rerata yang diikuti oleh huruf sama pada kolom yang sama menunjukkan tidak ada beda nyata pada uji Duncan Multiple Range Test pada. taraf 5\%. 
Tanda (-) menunjukkan tidak ada interaksi.

Hasil sidik ragam parameter panjang buah, diameter buah, dan kadar kemanisan buah menunjukkan bahwa parameter panjang buah perlakuan pupuk kandang berpengaruh nyata dan konsentrasi urine kelinci tidak berpengaruh nyata. Parameter diameter buah dan kadar kamanisan buah perlakuan pupuk kandang dan konsentrasi urine kelinci tidak berpengaruh nyata. Perlakuan pupuk kandang dan konsentrasi urine kelinci menunjukkan tidak ada interaksi. Nilai rerata panjang buah, diameter buah, dan kadar kemanisan buah dapat dilihat pada tabel 6 .

Tabel 6. Rerata panjang buah, diameter buah, dan kadar kamanisan buah pada perlakuan macam pupuk kandang dan konsentrasi urine kelinci.

\begin{tabular}{|c|c|c|c|c|}
\hline \multirow{2}{*}{$\begin{array}{l}\text { Urine } \\
\text { Kelinci }\end{array}$} & \multicolumn{3}{|c|}{ Pupuk Kandang } & \multirow[t]{2}{*}{ Rerata } \\
\hline & $\mathrm{P} 1$ & P2 & P3 & \\
\hline \multicolumn{5}{|c|}{ Panjang Buah (cm) } \\
\hline K0 & 10,67 & 9,89 & 11,22 & $10,59 \mathrm{p}$ \\
\hline K1 & 9,33 & 11,06 & 12,33 & $10,91 \mathrm{p}$ \\
\hline $\mathrm{K} 2$ & 9,89 & 11,78 & 13,44 & $11,70 \mathrm{p}$ \\
\hline K3 & 11,56 & 12,00 & 12,56 & $12,04 \mathrm{p}$ \\
\hline Rerata & $10,36 \mathrm{~b}$ & $11,18 \mathrm{~b}$ & $12,39 \mathrm{a}$ & $11,31(-)$ \\
\hline \multicolumn{5}{|c|}{ Diameter Buah (mm) } \\
\hline K0 & 36,98 & 35,97 & 36,17 & $36,37 \mathrm{p}$ \\
\hline K1 & 34,92 & 34,64 & 41,62 & $37,06 \mathrm{p}$ \\
\hline $\mathrm{K} 2$ & 40,64 & 35,96 & 38,03 & $38,21 \mathrm{p}$ \\
\hline K3 & 39,76 & 39,32 & 39,18 & $39,42 \mathrm{p}$ \\
\hline Rerata & $38,08 \mathrm{a}$ & $36,47 \mathrm{a}$ & $38,75 \mathrm{a}$ & $37,77(-)$ \\
\hline \multicolumn{5}{|c|}{ Kadar Kemanisan Buah $\left({ }^{\mathrm{O}}\right.$ brix $)$} \\
\hline K0 & 19,56 & 19,72 & 19,39 & $19,56 \mathrm{p}$ \\
\hline K1 & 19,17 & 18,94 & 19,00 & $19,04 \mathrm{p}$ \\
\hline $\mathrm{K} 2$ & 19,56 & 19,83 & 19,83 & $19,74 \mathrm{p}$ \\
\hline K3 & 19,56 & 19,89 & 20,28 & $19,91 \mathrm{p}$ \\
\hline Rerata & $19,46 \mathrm{a}$ & $19,60 \mathrm{a}$ & $19,63 \mathrm{a}$ & $19,56(-)$ \\
\hline
\end{tabular}

Keterangan: Rerata yang diikuti oleh huruf sama pada kolom yang sama menunjukkan tidak ada beda nyata pada uji Duncan Multiple Range Test pada taraf 5\%. Tanda (-) menunjukkan tidak ada interaksi.

Hasil sidik ragam parameter bobot segar tanaman tanpa buah dan bobot kering tanaman tanpa buah menunjukkan bahwa perlakuan pupuk kandang berpengaruh nyata dan konsentrasi urine kelinci menunjukkan tidak berpengaruh nyata. Perlakuan pupuk kandang dan konsentrasi urine kelinci menunjukkan tidak ada interaksi. Nilai rerata bobot segar tanaman tanpa buah dan bobot kering tanaman tanpa buah dapat dilihat pada tabel 7. 
Tabel 7. Rerata bobot segar tanaman tanpa buah dan bobot kering tanaman tanpa buah pada perlakuan macam pupuk kandang dan konsentrasi urine kelinci.

\begin{tabular}{|c|c|c|c|c|}
\hline \multirow{2}{*}{$\begin{array}{c}\text { Urine } \\
\text { Kelinci }\end{array}$} & \multicolumn{3}{|c|}{ Pupuk Kandang } & \multirow[t]{2}{*}{ Rerata } \\
\hline & $\mathrm{P} 1$ & $\mathrm{P} 2$ & P3 & \\
\hline \multicolumn{5}{|c|}{ Bobot Segar Tanaman Tanpa Buah (gram) } \\
\hline K0 & 44,22 & 32,89 & 48,78 & $41,96 \mathrm{p}$ \\
\hline K1 & 39,89 & 39,89 & 53,67 & $44,48 \mathrm{p}$ \\
\hline $\mathrm{K} 2$ & 36,44 & 36,78 & 42,33 & $38,52 \mathrm{p}$ \\
\hline K3 & 34,33 & 44,44 & 54,89 & $44,55 \mathrm{p}$ \\
\hline Rerata & $38,72 \mathrm{~b}$ & $38,50 \mathrm{~b}$ & $49,92 \mathrm{a}$ & $42,38(-)$ \\
\hline \multicolumn{5}{|c|}{ Bobot Kering Tanaman Tanpa Buah (gram) } \\
\hline K0 & 16,22 & 14,78 & 21,44 & $22,17 \mathrm{p}$ \\
\hline $\mathrm{K} 1$ & 17,11 & 16,33 & 25,00 & $22,41 \mathrm{p}$ \\
\hline $\mathrm{K} 2$ & 16,11 & 15,67 & 18,33 & $21,11 \mathrm{p}$ \\
\hline K3 & 16,00 & 18,33 & 23,89 & $23,89 \mathrm{p}$ \\
\hline Rerata & $16,36 \mathrm{~b}$ & $16,28 \mathrm{~b}$ & $22,17 \mathrm{a}$ & $22,39(-)$ \\
\hline
\end{tabular}

Keterangan: Rerata yang diikuti oleh huruf sama pada kolom yang sama menunjukkan tidak ada beda nyata pada uji Duncan Multiple Range Test pada taraf 5\%. Tanda (-) menunjukkan tidak ada interaksi.

Berdasarkan hasil sidik ragam, pada kombinasi perlakuan pupuk kandang dan konsentrasi urine kelinci menunjukkan adanya hubungan sinergisme (interaksi) pada parameter panjang sulur 1 MST dan panjang sulur 2 MST. Hal ini dikarenakan pemberian pupuk kandang mampu meningkatkan bahan organik yang ada di dalam tanah yang berfungsi sebagai sumber nutrisi bagi mikroorganisme. Pemberian urine kelinci mampu mendorong dan meningkatkan pembentukan klorofil daun, sehingga dapat meningkatkan kemampuan fotosintesis tanaman dan penyerapan nitrogen dari udara, dapat meningkatkan vigor tanaman, sehingga tanaman menjadi kokoh dan kuat, mengandung hormon auksin untuk membantu pemanjangan sel pada tanaman, meningkatkan daya tahan tanaman terhadap kekeringan, cengkaman cuaca, dan serangan hama penyakit, merangsang pertumbuhan dan cabang produktif (Marpaung, Karo, \& Barus, 2018).

Parameter diameter batang 1 MST dan bobot buah per tanaman menunjukkan adanya beda nyata terhadap pupuk kandang ayam dan konsentrasi urine kelinci 300 $\mathrm{ml} /$ liter. Hal ini diduga pupuk kandang ayam mampu memperbaiki sifat fisik, kimia, dan biologi tanah, pupuk kandang ayam mampu meningkatkan ketersediaan unsur nitrogen, fosfor, dan kalium yang cukup tinggi. Pupuk kandang ayam dapat mensuplai kebutuhan hara yang cukup bagi kelangsungan hidup mentimun (Wicaksana \& Sulistyono, 2017). Unsur fosfor dan kalium adalah hara yang banyak berperan dalam pembungaan dan pemasakan buah (Dewi, 2016).

Konsentrasi urine kelinci $300 \mathrm{ml} /$ liter menunjukkan ada beda nyata dikarenakan pupuk organik cair urine kelinci mengandung mikroorganisme yang dapat meningkatkan ketersediaan unsur hara bagi tanaman, terutama unsur nitrogen, phospor, dan kalium sehingga mampu mengurangi penggunaan pupuk anorganik dan meningkatkan pertumbuhan serta hasil yang maksimal. Menambahkan konsentrasi urine kelinci yang tinggi dapat mencukupi nutrisi pada tanaman, sehingga akan menghasilkan buah yang 
lebih besar. Dosis urine kelinci $300 \mathrm{ml}$ memberikan hasil tertinggi pada jumlah tandan bunga, jumlah bunga, jumlah buah, berat buah dan berat buah per tanaman.

Parameter panjang sulur 3, 4 MST, diameter batang 2,3,4 MST, jumlah daun 1,2,3,4 MST, jumlah bunga, bobot buah per buah, panjang buah, bobot segar tanaman tanpa buah, dan bobot kering tanpa buah menunjukkan ada beda nyata terhadap perlakuan pupuk kandang dan tidak ada beda nyata terhadap konsentrasi urine kelinci. Hal ini diduga karena unsur hara yang terkandung dalam pupuk kandang ayam sepenuhnya di translokasikan kepada bagian tanaman, memiliki unsur hara yang sangat baik untuk pertumbuhan vegetatif dan generatif pada tanaman mentimun, dimana tinggi tanaman dan jumlah daun akan mempengaruhi pertumbuhan tanaman terhadap bobot segar dan bobot kering tanaman. Pupuk kandang ayam mempunyai kemampuan mengubah sifat fisik, kimia, dan biologi tanah sehingga menjadi faktor yang menjamin kesuburan tanah (Sitanggang, Islan, \& Saputra, 2015).

Pupuk kandang ayam dapat mensuplai kebutuhan hara yang cukup bagi kelangsungan hidup mentimun. Berat kering merupakan akibat dari penimbunan hasil bersih dari asimilasi $\mathrm{CO} 2$ sepanjang musim pertumbuhan yang mencerminkan akumulasi senyawa organik yang berhasil disintesis tanaman dari senyawa organik terutama air dan $\mathrm{CO} 2$.

Konsentrasi urine kelinci menunjukkan tidak ada beda nyata diduga bahwa faktor lingkungan sangat mempengaruhi pertumbuhan dan hasil tanaman mentimun, salah satunya yaitu intensitas hujan yang tinggi menyebabkan kelembapan udara meningkat, pada kondisi ini laju translokasi tanaman menurun, sehingga pemberian unsur hara tidak dapat dipakai secara maksimal, serta tingkat serapan nitrogen yang tidak beda jauh cenderung rendah. Pernyataan ini sesuai dengan penelitian (Cholisoh, Budiyanto, \& Fuskhah, 2018), menyatakan bahwa serapan nitrogen mempengaruhi laju pertumbuhan tanaman karena unsur nitrogen sangat penting bagi tanaman sebagai pembentuk organ tanaman dan nitrogen termasuk hara yang mudah hilang disebabkan oleh penguapan dan pencucian. Cahaya matahari berperan penting dalam proses fotosintesis, sehingga sangat berpengaruh dalam pembuatan protein dan karbohidrat pada saat proses pembentukan buah (Efendi, 2020).

Curah hujan yang tinggi akan membentuk tekstur tanah yang pasir berlempung dan agak kasar, sehingga pergerakan akar dalam tanah tidak bebas dan unsur hara susah untuk diserap oleh tanaman. Tanaman mentimun dikenal sebagai tanaman yang tidak begitu tahan terhadap curah hujan yang tinggi karena dapat mengganggu pertumbuhan tanaman. Terlebih pada saat tanaman berbunga, curah hujan yang tinggi dapat menggugurkan bunga. Hujan yang terus menerus mengakibatkan sinar matahari tidak cukup kemampuan daun untuk berfotosintesis atau sangat rendah sehingga nutrisi untuk pertumbuhan buah kurang maksimal. Tanah yang sifat fisik, kimia dan biologinya kurang baik seperti becek dan banjir sering kali menghambat pertumbuhan tanaman mentimun, sehingga produksinya kurang maksimal dan kualitasnya rendah.

Parameter diameter buah dan kadar kemanisan buah menunjukkan tidak ada beda nyata terhadap kedua perlakuan tersebut. Hal ini diduga tanaman mentimun memiliki ukuran diameter buah yang relatif seragam yang sangat dominan ditentukan oleh faktor dalam tanaman mentimun itu sendiri, serta pemberian pupuk kandang ayam lebih efektif dalam memberikan tambahan unsur hara bagi tanaman mentimun yang selanjutnya akan dimanfaatkan untuk perkembangan buah. Tinggi rendahnya konsentrasi dan dosis sangat mempengaruhi kualitas obrix buah mentimun. Oleh sebab itu tingkat obrix tidak dipengaruhi sepenuhnya oleh kandungan unsur hara yang ada di dalam tanah. Faktor lingkungan berkemungkinan dapat mempengaruhi seperti intensitas cahaya dan lama penyinaran sinar matahari terhadap tanaman. Tanaman akan menyerap unsur hara selama 


\section{Pengaruh Pupuk Kandang dan Konsentrasi Urine Kelinci Terhadap Pertumbuhan dan Hasil Tanaman Mentimun (Cucumis Sativus L.)}

pertumbuhannya sehingga dapat meningkatkan proses fotosintesis dimana hasil fotosintat akan dimanfaatkan untuk pembesaran buah.

Pemberian konsentrasi urine kelinci pada parameter diameter buah dan kadar kemanisan buah menunjukkan tidak ada pengaruh nyata. Unsur hara yang paling berperan untuk menentukan diameter buah dan tingkat kemanisan yaitu unsur kalium. Ketersediaan unsur kalium yang cukup dalam tanaman dapat meningkatkan kualitas dan produksi buah seperti kadar gula. Buah yang belum matang memiliki rasa yang tidak manis karena kandungan karbohidratnya masih berbentuk pati (polisakarida). Seiring dengan proses pemasakan terjadi proses pemecahan senyawa secara enzimatis dengan bantuan fosforilase, glukoamilase, dan amilase.

Buah yang memiliki kadar air lebih dari $95 \%$ akan mudah busuk bila disimpan sehingga mudah pecah dan terasa lembek apabila dikonsumsi. Sesuai dengan hasil korelasi antara derajat kemanisan dan tebal daging buah membuktikan bahwa semakin tebal daging buah maka tingkat kemanisan akan semakin tinggi. Apabila daging buah semakin tebal maka kadar air juga akan semakin menurun sehingga derajat kemanisan akan semakin meningkat.

Pemberian pupuk dapat mempengaruhi pertumbuhan tanaman, hal ini diakerenakan adanya pemupukan dapat membantu tanaman untuk memperoleh unsur hara yang dibutuhkan tanaman sehingga dapat dimanfaatkan sebagai nutrisi bagi tanaman. Pemupukan yang lengkap dan berimbang sangat mempengaruhi pertumbuhan dan hasil tanaman mentimun, karena akan menambahkan dan mengembalikan unsur hara yang telah hilang baik tercuci maupun yang terbawa tanaman. Pemupukan berimbang yang harus diperhatikan adalah tepat jenis, tepat dosis, tepat waktu, tepat bentuk, dan tepat cara.

\section{Kesimpulan}

Terdapat Interaksi antara berbagai macam pupuk kandang dan konsentrasi urine kelinci terhadap tanaman mentimun pada parameter panjang sulur 1 MST dan 2 MST. Perlakuan yang paling baik adalah pemberian pupuk kandang ayam dan konsentrasi urine kelinci $300 \mathrm{ml} /$ liter pada parameter diameter batang 1 MST dan bobot buah per tanaman.

Pupuk kandang ayam memberikan hasil lebih baik pada parameter panjang sulur 1,2,3,4 MST, diameter batang 1,2,3,4 MST, jumlah daun 1,2,3,4 MST, jumlah bunga, bobot buah per buah, bobot buah per tanaman, panjang buah, bobot segar tanaman tanpa buah, serta bobot kering tanaman tanpa buah.

Konsentrasi $300 \mathrm{ml} /$ liter memberikan hasil lebih baik pada parameter panjang sulur 1 MST, 2 MST, diameter batang 1 MST, dan bobot buah per tanaman.

\section{Bibliografi.}

Cholisoh, Khilmi Nur, Budiyanto, Susilo, \& Fuskhah, Eny. (2018). Pertumbuhan dan produksi tanaman sawi (Brassica juncea 1.) akibat pemberian pupuk urin kelinci dengan jenis dan dosis pemberian yang berbeda. Agro Complex, 2(3), 275-280.

Dewi, Wahyu Wardiana. (2016). Respon dosis pupuk kandang kambing terhadap pertumbuhan dan hasil tanaman mentimun (Cucumis sativus L.) varietas hibrida. VIABEL: Jurnal Ilmiah Ilmu-Ilmu Pertanian, 10(2), 11-29.

Efendi, Efendi. (2020). Pengaruh Komposisi Media Tanam dan Konsentrasi POC Urin Kelinci Terhadap Pertumbuhan dan Produksi Tanaman Selada (Lactuca sativa L.). Biofarm: Jurnal Ilmiah Pertanian, 16(1).

Hartatik, Wiwik, Husnain, Husnain, \& Widowati, Ladiyani R. (2015). Peranan pupuk organik dalam peningkatan produktivitas tanah dan tanaman. Jurnal Sumberdaya Lahan, 9(2). 
Kardinan, Agus. (2016). Sistem pertanian organik. Intimedia. Malang.

Marpaung, Agustina E., Karo, Bina Br, \& Barus, Susilawati. (2018). Respon Beberapa Jenis Kompos Dan Poc Terhadap Pertumbuhan Dan Hasil Kubis. Jurnal Agroteknosains, 2(2).

Masitoh, Wirianti, Puspitorini, Palupi, \& Widiatmanta, Jeka. (2018). Pengaruh Dosis Pupuk Bio Slurry Cair Dan Jarak Tanam Terhadap Pertumbuhan Dan Hasil Tanaman Mentimun (Cucumis sativus L.). Viabel: Jurnal Ilmiah Ilmu-Ilmu Pertanian, 12(2), 32-39.

Ningrum, Dwi Aprilia. (2018). Respon Pertumbuhan, Hasil Dan Mutu Varietas Brokoli (Brassica oleracea L. var. italica) Pada Berbagai Jarak Tanam. Yogyakarta: Univesitas Pembangunan Nasional Veteran Yogyakarta.

Noviyandri, Putri Rahmi, \& Nasution, Abdillah Imron. (2017). Pengaruh Ekstrak Buah Timun Suri (Cucumis sativus L.) sebagai Antibakteri Alami dalam Menghambat Pertumbuhan Enterococcus faecalis. Journal Caninus Dentistry, 2(3), 111-116.

Nurjanah, Nunung, \& Ihsan, Nur. (2013). Ancaman! Di Balik Segarnya Buah \& Sayur. Puspa Swara.

Purnomo, Rudi, Santoso, Mudji, \& Heddy, Suwasono. (2013). Pengaruh berbagai macam pupuk organik dan anorganik terhadap pertumbuhan dan hasil tanaman mentimun (Cucumis sativus L.). Jurnal Produksi Tanaman, 1(3).

Ruminta, Ruminta, Wahyudin, Agus, \& Hanifa, Muhammad Lukman. (2017). Pengaruh Pupuk NPK dan Pupuk Organik Kelinci terhadap Hasil Sorgum (Sorghum bicolor [Linn.] Moench) di Lahan Tadah Hujan Jatinangor. Kultivasi, 16(2).

Sitanggang, Asbon, Islan, Islan, \& Saputra, Sukemi Indra. (2015). Pengaruh Pemberian Pupuk Kandang Ayam dan zat Pengatur Tumbuh Giberelin Terhadap Pertumbuhan Bibit Kopi Arabika (Coffea Arabica L.). Riau: Riau University.

Soraya Santi, Sintha. (2012). Kajian Pemanfaatan Limbah Nilam Untuk Pupuk Cair Organik. Jurnal Teknik Kimia, 2(2), 170-174.

Wicaksana, Puguh Catur, \& Sulistyono, Nantil Bambang Eko. (2017). Aplikasi Pupuk Kandang Ayam dan Mikroorganisme Lokal (MOL) Daun Gamal Terhadap Produksi dan Mutu Benih Mentimun (Cucumis sativus L.). Agriprima, Journal of Applied Agricultural Sciences, 1(1), 72-85.

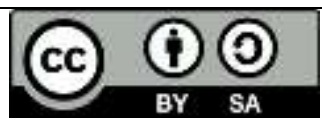

This work is licensed under a Creative Commons Attribution-ShareAlike 4.0 International License. 